\title{
Pain Assessment
}

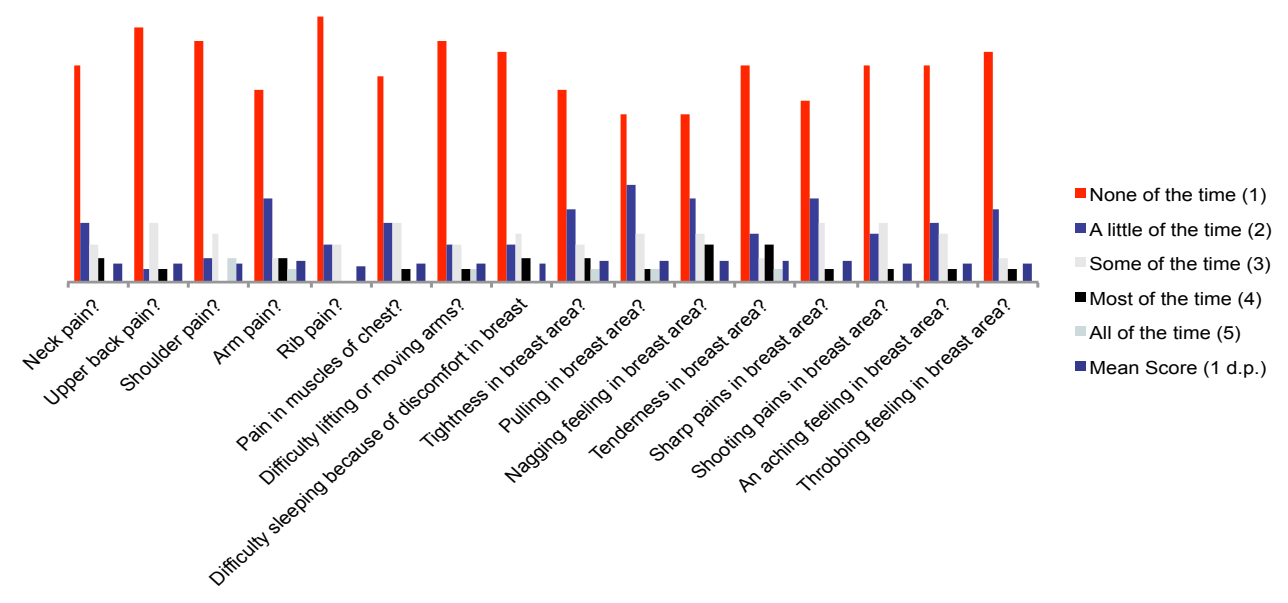

